\title{
The Speaking Skill of Indonesian Language of Students Grade IV SDN Inpres Dasan Baru
}

\author{
Syahdan; Amrullah ${ }^{1}$; Khairul Umam ${ }^{2}$ \\ ${ }^{1}$ Lecture of Postgraduate, Universitas Mataram, Lombok, Indonesia \\ ${ }^{2}$ Student of Magister of Indonesian Language Education, Postgraduate, Universitas Mataram, Lombok, Indonesia
}

http://dx.doi.org/10.18415/ijmmu.v6i4.1002

\begin{abstract}
Indonesian Language is still difficult to learn by almost every beginner learner who lives in a rural area of Indonesia which is far enough from the capital city. In this situation, Indonesian language which stands as an official language in this country becomes a second language whereas, the traditional language is, a mother tongue. This research is a qualitative research that aims to describe speaking skill of Indonesian language of the fourth grade of Elementary School at SDN Inpres Dasan Baru, and some factors that influence the development of Indonesian language speaking skill. The data is collected through four different ways: interview, observation, documentation, and purposive tasks. After analyzing the whole results, the researchers had found that the score of speaking skill is at medium level of the average, the development of speaking skill is mostly influenced by their family socio-economy status, relation of friendship, bilingualism, and environment.
\end{abstract}

Keywords: Speaking Skill; Indonesian Language; Fourth Grade Students

\section{Introduction}

The ability to speak Indonesian language is a type of direct communication used in classes and other formal circumstances, this fact makes it one of the capabilities that elementary school students must master. Normally, Elementary students, or at least high class (grade IV-VI) should have been able to speak Indonesian language well. However, the necessity to achieve a certain point is not forever going along with the reality that occurs in the field. Furthermore, the fact that there are many students scattered throughout Indonesia who have a native language is not Indonesian, but the language of the local area. Thus, Indonesian language is the second language obtained after the mother tongue that is commonly heard around the local environment (compare Chaer, 2003:167). For students in the first language is not Indonesian language, of course this becomes a difficulty.

Departing from the paradigm, researchers interested in conducting research on how students come from a rural area of the mother tongue speaks in a second language. One of the places that researchers consider representative to be the research site is SDN Inpres Dasan Baru. Then, researchers are interested in researching the IV class, on the basis of consideration that the class is middle grade and 
representative for research. SDN Inpres Dasan Baru is a state institution located in the Dusun Dasan Baru, Murbaya Village, Pringgarata sub-district, central Lombok Regency, West Nusa Tenggara province. Like most areas in Lombok, Dasan Baru is also one of the areas where the first language is Sasak language. With the condition of all students coming from Dasan Baru and its surroundings, the majority of students at SDN Inpres Dasan Baru are also children of Sasak language speakers. This is certainly potential as one of the obstacles faced by the students and teachers in the journey to achieve the mastery of Indonesian language during the school, this situation will create a compelling appeal between the mother tongue and a second language. Thus, there can be significant influences from the first language to the ability to speak a second language, which in turn will also affect the proficiency of Indonesian language as a second language. Researchers assumed that mother tongue is not the only one that affects the ability to speak a second language. Therefore, researchers feel the need to do a deepening of students' speaking skills, which ultimately lead researchers to factors affecting the development of Indonesian language proficiency. Tarigan (1998:5) shared that speaking skill is an expression that is the pronunciation of articulated sounds with the intention of conveying ideas and feelings that have at least two main conditions: audible and visible. Ahmadi (1990:18) and Yuanita (1996:15) also provided a similar understanding, that speaking is a skill of producing sound in the form of spoken language on the basis of conveying intentions, ideas, feelings and desires. It can be concluded that speaking is a creative activity that relies heavily on the ability of a speaker to convey feelings into communicative sentences.

Keraf (1989:320) shared that at least, Speaking has three purposes. The first objective is to notify/report, that is, to embed knowledge to the listener. The second goal is to entertain, which is to speak on the basis of wanting to instill a sense of delight in listeners. The third goal is to persuade/convince, i.e. speaking to move listeners. The distinctive feature of Speaking is: threaded, an interaction activity of at least two persons, temporary, occurring in a special setting, alpha punctuation, limited words, and very dependent on the linguistic experience of speaker. With all the dynamics of this speaking skill, it is important to know what factors are likely to affect the speaking ability of a person.

Ahmadi (1990:19) shared that the main purpose of a speaking teaching is to allow learners to speak eloquently, speak clearly, be accountable and to form the critical hearing. Sabana (1986:19) also shared that speaking learning will not be detached from approaches, methods, and techniques. Language teachers often find the difficulties when determining appropriate learning strategies to improve the speaking skill. There are several criterias for speaking skill assessment. One of these references is Brooks ' opinion (1964:252) which shared that to assess a person's speaking ability can be done by observing five key factors: a) the clear clarity of the mention of vocal sounds and consonants, b) pay attention to the syllable pressure as well as the intonation pattern, c) notice how far the speaker's comprehension of speech is demonstrated, d) noticing the sequence and shape of the speech comparing it to the raw grammar, and e) pay attention to the extent to which it is capable of monetising the speech that makes it sound like the native speaker of the language. Shihabuudin (2009:198-199) shared a limitation that the assessment of the speaking ability of a speaker can be done by observing aspects of pronunciation, grammar, vocabulary, smoothness, conversation content and understanding. In this case the researchers concluded that the ability to speak of a speaker can be assessed by observing aspects of pronunciation oriented to the accuracy of sound and intonation, grammar, vocabulary that selected by the speakers, smoothness, and how deep understanding of speakers. After discussing the ability to speak, it needs to be addressed about things that influence the ability to speak of speaker.

The Speaking skill is commonly influenced by few factors. Hurlock (2008) shared that the ability to speak of child is influenced by several factors: health, intelligence, socio-economic conditions, gender, desire of communication, family status, order of birth, relationship with peers, and personality. Hildayani (2011) shared the same opinion that speaking skills are influenced by intelligence, gender, physical condition, family environment, economic conditions, social settings, and bilingualism. 


\section{Research Methods}

This research is a qualitative study referring to the discovery of unique facts during the study. As it is known, by its qualitative nature, the role of the direct involvement of the researchers during the field is greatly emphasized (Arikunto, 2006:12). The students population that studied was 11 students, with this condition, researchers applied the study of the population where everey students were sampled. In addition, researchers also implemented data triangulation and method triangulation, Where the data source is more than one and the method used is also more than one (Mahsun, 2018:236-237). There are four types of methods used in this study: interviews, observations, documentation and assignments. The interview was conducted to the students as well as the teacher, which allowed the researchers to get a preliminary picture, then verified and developed (Syamsuddin and Damaianti, 2015:94). Observations were made to get a more exclusive and insightful picture of research targets. The form of documentation in this study was a video recording that was later altered in narrative form. The assignment in this study is to ask students to speak Indonesian language in an interview session where each student has a color marker as prize, this is to bring out the full potential of students ' speaking skills.

\section{Discussion}

The grade IV consisted of eleven students: Alfa, Ardian, Celsy, Dendi, Hafia, Fira, Hesti, Ridho, Muliana, Galih, and Yunita with teacher class held by Hardianto. Ten students spoke a mother tongue (Sasak) as the first language. As for another student, Fira speaks Indonesian as the first language. However, communication in the classroom is still dominated by Sasak language and forms informal communication. It makes teacher and researchers need to strive harder to unleash the maximum potential of students, for teacher to improve student speech skills, and for researchers to get results in accordance with research objectives.

\section{The speaking Skill of Indonesian language of students grade IV SDN Inpres Dasan Baru}

After going through the data retrieval process, researchers analyzed the results based on the data obtained during the field research. Here is the results describing students ' speaking skills. Each aspect of the assessment is categorized as follows: Very low rated by 1 , low rated by 2 , middle score is rated by 3 , well rated 4, and very well is rated by 5 . The scores that appear are then aggregated and divided so that the average score of every aspect of each student's assessment is found, a similar way is also applied to get the average of the class score. Based on the final result, the average score of the entire students is at a moderate level. It is really a low score considering that the Indonesian language itself is the national language that should have been mastered at that level. Even with this score, there is something interesting to cover, i.e. some students are known to have better scores than others. The differentiator will be discussed on the discussion of factors affecting students ' speaking skill.

\section{Factors affecting the development of students ' speaking skills}

In this section will be explained about several factors affecting the students ' speaking skill. Due to the limited research, researchers can only explain a few factors and do not in all the factors mentioned previously. The factors are: socio-economic and family status, relation of friendship, bilingualism, and environment. Family socio-economic Status affects students ' speaking ability to be seen in the case of Fira. Based on the results of the interview with the teacher, it is revealed that she comes from the background of both parents who are professional teacher who are paid by the country. Thus, her parents ' income and social status are also at a good level. It is also known that the first language of Fira is Indonesian language. This case is because Fira's mother is a Javanese, which of course has difficulty to speak in Sasak, then Fira is used to speak Indonesian language since childhood, she is the only student whose first language is Indonesian language. This whole situation makes her the best speaker of 
Indonesian language in the classroom. The uniqueness of Fira's case also affects her friends. It is known that Fira has three close friends: Celsy, Hesti, and Yunita. These three close friends of Fira have a relatively better score than other students. Based on the observations conducted by the researchers, it is known that when these three friends of Fira spoke with Fira, they did code switching to the Indonesian language. Their proximity is not only in class, on holidays they also play together. This closeness has forced the ability to speak these three friends of Fira growing more rapidly than other students. The circumstance that may slow their speaking skills is the condition of bilingualism.

Bilingualism is a natural obstacle for all students. The first language in the region is known as Sasak, where the language is very strong in its influence because it is a daily language. Students may learn a second language through television, but practicing it is a different matter. The degree of difficulty can still not be overcome by them. Thus, practicing a second language with the strong influence of the first language can cause chaos in the second language narrative. This can be seen from the fact that students are still interfering with code swithing and code mixing when the teacher asks them to speak the Indonesian language in front of the class, even students often speak Indonesian language but are influenced by the Sasak language rules system. This situation is realized by teacher so that teacher gave adjustment action by arranging a classroom environment conducive to the development of a second language.

The classroom environment has been created by the teacher as a condition that supports the development of speaking skills. It is understood by researchers from the way teacher organized the class environment. The teacher speaks Indonesian language when explaining the lesson and communicating with the students. Teacher will do the code mixing and code swithing when the students are in a difficult time of understanding the teacher's speech, after students understand then the teacher will immediately repeat the same explanation in Indonesian language. Another thing that teacher do is that he intentionally gives the opportunity to speak more to Fira whose ability to speak Indonesian language is better than other students. This situation indeed makes Fira dominate the conversation with the teacher, but it is good to give the stimulus to other students. It is also known that teacher often divide the group by separating students who have better speaking skills followed by members of other groups who have low speech ability. In addition, teacher also often give gifts to students who are able to complete the task of speaking in front of the class well.

\section{Conclusions}

Here is the conclusion found based on the study. After conducting an in-depth analysis, researchers arrived at the final decision that the average proficiency score of the fourth graders of SDN Inpres Dasan Baru was in the middle level. By the result, there is clearly a state of appeal between several students, some of them show low scores, some are contributing good scores.

The factors that affect the situation are divided into two factors: factors that help the development and there are also things that prevent. The things that help to develop are: social economic factors of family, relationships between friends and class environment conditioning. The factors that inhibit are the condition of bilingual and local community environment.

\section{References}

Ahmadi. M. (1990). Strategi Belajar-Mengajar Keterampilan Berbahasa dan Apresiasi Sastra. Malang: Yayasan Asih Asah Asuh.

Arikunto. S. (2006). Prosedur Penelitian Suatu Pendekatan Praktik. Jakarta: Rineka Cipta. 
Chaer. A. (2003) Psikolinguistik: Kajian Teoretik. Jakarta: Rineka Cipta.

Hildayani, Rini, dkk. (2011). Psikologi Perkembangan Anak. Jakarta: Universitas Terbuka.

Hurlock. (2008). Psikologi Perkembangan. Jakarta: Erlangga Press.

Keraf. G. (1989). Komposisi (Sebuah Pengantar Kemahiran Berbicara. Flores: Nusa Indah.

Mahsun. (2004). Metode Penelitian Bahasa Tahapan Strategi, Metode, dan Tekniknya. Jakarta: Rajawali Persada.

Sabana. M.S. (1986). Strategi Belajar Mengajar Bahasa Indonesia. Berbagai Pendekatan, Media, Tekhnik, dan Media Pengajaran. Bandung: CV Pustaka.

Shihabuddin. H. (2009). Evaluasi Pengajaran Bahasa Indonesia. Bandung: UPI.

Syamsuddin and Damaianti. V.S. (2015). Metode Penelitian Pendidikan Bahasa. Bandung: Rosda Karya.

Tarigan. H.G. (1998). Berbicara sebagai Suatu Keterampilan Berbahasa. Bandung: Angkasa.

Yuanita. S. (1996). Sukses Berbicara dan Berkomunikasi. Yokyakarta: Genius Publisher.

\section{Copyrights}

Copyright for this article is retained by the author(s), with first publication rights granted to the journal. This is an open-access article distributed under the terms and conditions of the Creative Commons Attribution license (http://creativecommons.org/licenses/by/4.0/). 